\title{
Heategevus- ja solidaarsusmeditsiini problemaatikast Eesti näitel
}

\author{
Mare Kõiva \\ Eesti Kirjandusmuuseumi folkloristika osakonna juhtivteadur \\ mare@folklore.ee
}

\begin{abstract}
Teesid: Alternatiiv-, rahva- ja riikliku meditsiiniteenuse üks puutekoht on vabatahtlik abi ja ühisfinantseerimine, annetusmeditsiin, heategevusliikumine või solidaarne heategevus. See vabatahtlik tegevus haarab paljusid eri vanuses ja erinevate võimalustega inimesi ning on laiem kui elustiilimuutused ja olemuslik pööre omamaiste tegevuste ja vaadete suunas. Globaalne trend jääb mitme uurisvaldkonna vahealale, ent selle sügavalt inimlik sõnum, ühisabi hädaolukorras inimestele on traditsiooniliste abistamistraditsioonide jätkumine tänases ühiskonnas. Heategevusmeditsiin on avanud uusi vaatlusteemasid ka humanitaarseteks uuringuteks. Artikkel vaatleb riiklike ja kohalike institutsioonide tervist ja nt raske tervisekahjustusega isikute hakkamasaamist toetava tegevuse joonist, erinevate meediakanalite tuge terviseprobleemidega isikutele ja isiku vabal tahtel põhinevat vabatahtlikku abi. Artikkel alustab vaatlust, kas ja missugune koht on solidaarsusel tänases meditsiinis ja hoolekandes, missugused on heategevusmeditsiini jooned, lähenemisviisid ja tulemused Eestis. Milliseid küsimusi tõstatab heategevus? Kas meil on tegemist mitte üksnes meditsiini- ja tervisetemaatikaga, vaid humaansete fraktalitega?
\end{abstract}

Märksõnad: abistatud suitsiid, altruism, annetusmeditsiin, solidaarsus

\section{Eesti meditsiinisüsteemi taustast}

Üks meie töörühma usundi- ja meditsiini-uuringuid oli seotud globaalsete trendide jälgimisega Eesti meditsiinimaastikul, hõlmates suhteid alternatiiv-, rahva- ja riikliku meditsiiniteenuse vahel ja erinevaid toimetulekumehhanisme (Kõiva 2020; Hiiemäe \& Kalda \& Kõiva \& Voolaid 2020; Hiiemäe \& Utriainen 2021; Kõiva 2021 jm). Postsotsialistliku meditsiinisüsteemi üks puutepunkt erinevate ühiskonnakihtide ja meditsiinisüsteemide vahel on heategevusmeditsiin ja kogukondlik finantseerimine. Heategevus ei iseloomusta üksnes meditsiinisüsteemi, vaid haarab erisuguseid vabatahtlikke tugiteenuseid, näiteks võimalust rahastada Hooandja kaudu erinevaid kunsti- ja kirjandusprojekte, muude liikumiste kaudu abistada spordi-jm harrastusviisi või õpitegevust. Olen sellist tegevust nimetanud solidaarseks heategevuseks, sest vabatahtlik annetamine haarab paljusid eri vanuses ja erinevate võimalustega inimesi, kuid eriti meditsiini puhul on põhjust arvestada solidaarsusega. 
Folkloristidele on tuttav eelmistel sajanditel külades toiminud vastastikune abi talgute ja ühistööde vormis, abi õnnetuste ja konfliktide järel, ühisabi liiga vaestele isikutele või üksikemadele, samuti kogukonna-põhine hoolekanne haigestunute, väetite ja vanade eest, aga ka näiteks tugisüsteem vanemate surma korral. Ükski teemadest pole leidunud põhjalikumat käsitlemist viimastel kümnenditel, vaatlemata on ka sotsialismiperioodil laialt kasutatud vanad ühistöö ja vastastikuse abi mudelid, sh tugi vaeslastele. Sellisel abil on sügavalt inimlik sõnum, tegemist on traditsiooniliste tavade jätkumisega. Samas võib üldistada varasema perioodi põhjal, et Eestis oli geneetilise koodi ehk sugulastele ja hõimlastele abi osutamise kõrval oluline kogukonna toetus oma liikmetele. On üpris selge, et varasemad suulised lepped vastastikuseks tagasimakseta aineliseks abiks olid seotud katastroofide, tulekahjude, üleujutuste jm käigus kannatanud isikutega, samuti orbudega jne ning eeskätt toimis see külakogukondade ja sugulussidemete raamides. Invaliidsus ja haiguse ravikulud kogukondliku abi ja hüvitamise hulka standardselt ei kuulunud.

Neuroteadused ja geneetika on osutanud inimeste kaasasündinud empaatiale ja sügavale rahuldusele, mida pakub abi saamine ja abi andmine (vt lähemalt Sterling 2018, 2020). Ent vaatamata põhiolemuslikule omadusele väärivad tähelepanu vastastikune empaatiast ja kirjutamata moraalinormidest ajendatud abi eksistentsiaalse defitsiidi olukorras, samuti juhul kui on vaja korvata teise isiku või üldse ühiskonnas puuduvat ressurssi.

Postsotsialistlik meditsiin Eestis tähendab riiklikku polikliinikute, taastusravikeskuste ja haiglate süsteemi, mis on ravikindlustatud isikutele üldjuhul tasuta. Samuti on olemas ühtne ravikindlustuse süsteem, mis tagab inimestele teenused ja ravikulude tasumise haigekassa poolt. Kindlustatud on inimesed, kelle eest maksab sotsiaalmaksu tööandja või inimene ise. Lisaks on Eestis õigus ravikindlustusele veel mitmel rühmal; nt kuni 19aastastel lastel, õpilastel, üliõpilastel, ajateenijatel, rasedatel, töötutel, lapsehoolduspuhkusel olijatel, ülalpeetavatel abikaasadel, pensionäridel, puudega inimeste hooldajatel, osalise või puuduva töövõimega inimestel, doktoranditoetuse saajatel, loometoetuse saajatel, usulise ühenduse registrisse kantud kloostri nunnadel ja munkadel ning haigekassaga vabatahtliku kindlustuslepingu sõlminutel (RaKS 2002). Kulud töötaja sotsiaalmaksule on tööandja kanda, need on $33 \%$ palgast, millest $13 \%$ läheb haigekassa käsutusse.

Paralleelselt riikliku süsteemiga eksisteerib tasuline meditsiin, kus arstiteenuse, analüüside ja ravi eest maksab patsient. Kuna tasuline meditsiin ei taga paremat kvaliteeti ja lisauuringute vajadusel tuleb ka nendega seotud kulud kanda patsiendil, on eelistatud tasuta meditsiiniteenus. Tervisetrendi kuulub haigusi ennetav ja tervist säilitav suhtumine ja seda soodustav käitu- 
mine, mida markeerib osalemine erinevatel kursustel, tervisliku toitumise ja teraapiate harrastamine.

Niisiis on inimestel olemas õigus ja võimalus tasuta meditsiiniabile, haiglaja taastusraviteenusele ning suur osa elanikkonnast on kaetud tasuta teenuse võimalustega. Siiski on kallist meditsiinitehnikat, teenuseid ja ravimeid, mis ei leidu toetatavate ravimite nimekirjas või mille puhul inimene vajab head rahalist seisu, et olukorrast välja tulla ja just siin tulevad appi alternatiivsed võimalused nagu vabatahtlik abi.

Annetamine annab lootuse just neile, kes ei suuda katta ülikallite farmaatsiatoodete hinda, kes põevad haruldasi haigusi, vajavad erakordseid operatsioone, institutsioonidele, kellel on vaja hirmkallist aparatuuri. Omakorda ootavad tuge ka erakorraliste haigete ja raskete puuetega inimeste külad (nt Maarja küla, SOS küla jt), mis vajavad tegevustoetust. Heategevuslikud initsiatiivid on nimetatud valdkondades väga efektiivsed ja oodatud.

Minu uuringud keskendusid ennekõike väikese ja keskmise sissetulekuga inimeste isiklikele annetustele Eesti näitel. ${ }^{1}$ Kuigi esil on jõuluannetused, on heategevus aastaringne töö, mitte pelgalt jõulude ja uusaasta meeleolust kantud tegevus. Artikkel tugineb ennekõike meditsiinifolkloristikas arendatud võimalustele, mõnevõrra on kasutatud meditsiini ajaloo ja sotsiaalantropoloogia võimalusi, mida Raymond Firth (1996) on defineerinud kui uurimissuunda, mis tegeleb meeste ja naiste suhetega ühiskonnas, vaatleb käitumismustreid, institutsioone ja tõekspidamisi, mis iseloomustavad inimesi eri tüüpi ühiskondades. Sotsiaalsel antropoloogial on kaks olulist tunnust, mis eristavad neid sotsiaaluuringute muudest valdkondadest. See on sisuliselt võrdlev, inimkäitumist kõigis ühiskonnavormides ja mis tahes ühiskonnaosas selle variatsioonides vaatlev ja selliste variantide tähendust avav suund. See definitsioon on lähedane folkloristika ja meditsiinifolkloristika olemusele, mis tegeleb samuti maailmavaatelise ja käitumusliku külje variatiivsuse ja võrdlemisega.

Artikli esmane vajadus oli luua ülevaade meditsiinilise diagnoosiga isikute võimalustest Eestis ja eesmärk vastata küsimusele, kas tänases meditsiinis on kohta solidaarsusel ja missugused on heategevusmeditsiini jooned, lähenemisviisid ja tulemused Eestis. Kuidas mõjutavad meditsiinikäitumist modernistlikud dihhotoomiad, meditsiiniteemalised arutelud, teaduslike uurimistulemuste kättesaadavus? Milliseid küsimusi tõstatab heategevus? Kas meil on tegemist hoopis humaansete fraktalitega? Eriti arvestades, et empaatia on neuroteaduste poolt tõestatud kui geneetiline omadus, mis pakub rahuldust nii saajale kui andjale (Sterling 2018, 2020)? Üldiseid jooni järgiva ülevaate kõrval keskendun heategevusmeditsiinile rõhuga kaasaval finantseerimisel kahe meditsiinilise abi juhtumi ja sellest mõnevõrra põikuva abistatud suitsiidijuhtumi näitel. 
COVID-19 pandeemia rikkalik andmestik lubab vaadelda heategevusmeditsiini vastupidavust kriisiolukorras ja samuti selle jätkusuutlikkust.

\section{Vabatahtlik abi ja altruism}

2019. aasta üleilmsel antropoloogia ja etnoteaduste liidu (IUAES) kongressil Poznanis püstitati meditsiiniantropoloogia sektsioonis küsimus, kas solidaarsusel põhinenud sotsialistliku meditsiini solidaarsuspõhimõtted on säilinud postsotsialistlikus meditsiinis või on need ideed kadunud. Küsimuse püstitus oli igas mõttes üllatav, sest mõte nõukogude meditsiinist kui solidaarsusmeditsiinist tundus võõras. Jah, meditsiiniteenus oli põhimõtteliselt kõikidele võrdselt kättesaadav tasuta hüve, riiklikult rahastatav, ent seotud maksusüsteemiga. Osa ravikuludest tuli kanda sanatooriumites ja taastusravikeskustes, massaaž ja füsioteraapia olid tasuta, nagu ka erinevad analüüsid ja vaktsiinid. Medikamentide eest tuli tasuda. Mis selles süsteemis täpselt solidaarsusega seotud oli, on edasise uurimise küsimus ja seni vastuseta. Kogesin sotsialismi ajal selle süsteemi tuhandet vormi ja nägu, kuid ei oska isegi vastata, kas meditsiiniteenus oli tasuta ka neile, kes ametlikult ei töötanud ja muudele mittestandardsetele kodanikele. Privileegideta mittetöölisklassi esindajana tean, et eriarsti abi saamine võis olla probleem, ent saan sama hästi aru, et mu praegune humanitaari-amet jätab mu samuti teenuste äärealale, aga ka see on pigem uurimisküsimus kui soov jagada muljeid.

Eesti kui suhteliselt hierarhiata, kuid samas pikalt ametliku heategevuse ja filantroopiata ühiskonna juures on ühisrahastamiste ja muude abivormide naasmine olnud üks muutumisi kodanikuühiskonna suunas. ${ }^{2}$ Samas on üldine sissetulekute väiksus seadnud küsimusi, kas ühiskond on võimeline heategevusaktsioonideks ja millisel määral see saab toimida.

Euroopas ja mujal on vabatahtlik abi eksisteerinud aastasadu, kuid selle sisu ja vorm on muutunud. Näiteks taandus naiste ja kirikute-kloostrite abi haigete eest hoolitsemisel 19. ja 20. sajandil riiklike organisatsioonide ja nn kodanikuühiskonna heategevuse ees (Vasold 1999; USA vaeste kodanike meditsiiniabi seoseid heategevusliikumisega vt Engel 2006). Liikumise uusimad vormid on esile tõusnud 1990. aastatest alates ja hõlmavad lisaks solidaarsusele altruismi ja humanismi printsiipide väärtustamist, sh ligimesearmastust. Vabatahtlik abi on enim seotud mõistega isiksuse vaba tahe, mis suunab meid abistama kehva majanduslikku, tervislikku või sotsiaalsesse olukorda sattunud inimesi. Abi vajavad elukohavahetuse või katastroofi tõttu kodu kaotanud isikud, kes on sattunud varjupaika või pidanud rändama kodust kaugemale. Sellises olukorras on igasugune altruistlik osavõtt vaimsest füüsilise ja majandusabini teretulnud. 
Heategevusmeditsiini vahendavad organisatsioonid tagavad juurdepääsu ka uutele ravivõtetele ja medikamentidele ja aitavad leida lahendusi meditsiinilistele probleemidele, mida tavavahenditega lahendada ei saa. Näiteks koondab Heategevusmeditsiini Koalitsioon Inglismaal kümmet heategevusorganiatsiooni, mis tegutsevad muuhulgas Alzheimeri tõve ja vähi-uuringutega ning organisatsiooni peamine ülesanne on rahastada teadusuuringuid ja jälgida patsientide huve (CMAC 2020).

Euroopa heategevusmeditsiin on olnud viimastel kümnenditel mitmest aspektist vaatluse all, hõlmates näiteks Inglismaa ja muude piirkondade juures vaadet rohujuure tasandilt, aga ka sotsiaalseid, klassi, sugupoole, võimu, valitsuse ja teisi valdkondasid (Barry \& Jones 1991; Engel 2006: 127-143 jj; Borsay 1999; Borsay \& Shapely 2016 [2007]; Vasold 1999). Tähelepanu on saanud ka linnastumise põhjustatud muutused ja heategevusorganisatsioonide saja-aastane ajalugu. Anne Borsay ja Peter Shapely (2016 [2007]: 3) toonitavad siiski, et uurimistöö piirdub tihti institutsioonide, annetajate, administraatorite ja professionaalidega. Nemad saavad ka suure osa meediatähelepanust ja leiavad kajastuse aastaaruannetes jm, millega kogu protsessi kajastamine jääb suhteliselt ühekülgseks. Uurimisteema teine pool, mis vaatleb vaeste või sotsiaalse teise rolli antud küsimuses, on ammu tunnistatud tähtsaks vaatepunktiks, kuid uurimise keskmes on see harva. Vaatamata pingutustele tuua sotsiaalsed suhted ja sotsiaalse teise kogemused teadustöö keskmesse ja üldisemalt vaadata probleemi nn alt-üles (nt Borsay \& Shapely 2016 [2007]; Bialecki \& Daswani 2015; Coleman 2006, Sarad et al. 2012), on teema endiselt alauuritud. Veel on mitmes riigis põhjalikumalt käsitletud filantroopia ajalugu, mis on olnud korduvalt ühiskonna sotsiaalse külje uuenduslike ja liberaliseerivate arengute tagamaa (vrd Kidd 1996: 182; Gorelova \& Surovtseva \& Sechenov 2014 jt). Pööre filantroopias ehk ühiskonna rikkaimate praktika jagada oma sissetulekud oma eluajal heategevuseks sai alguse 1990. aastate lõpul, kuid pöördeliseks kujunes miljardäride Bill Gatesi ja Warren Buffetti algatus "The Giving Pledge", millega kutsuti USA rikkaimaid inimesi annetama enamikku oma varandusest heategevuslikel eesmärkidel (Mänd et al. 2011: 20), filantroopia on laienemas ka Eestis (Valge \& Kübar \& Sarapik 2020).

Kuna vananemine on Euroopas ja ka Jaapanis terav küsimus, siis on tegemist riiklikult rahastatud teadusuuringute eelisteemaga, millega kaasuvate valupunktidega tegelevad teaduse tippkeskused mitmel pool maailmas (nt Jyväskylä, Tampere ja Helsingi Ülikooli tippkeskus Research on Ageing and Care 2018-2025). Elustiilimuutustega laieneb heategevusmeditsiin heaoluühiskonna tüüphaigusi (diabeet, rasvumine, südamehaigused, stress) ennetava tervisemudeli arendamisele ja rakendamisele: inimesi kaasatakse aktiivselt osalema haiguste ennetamises, enda ravimises ja panustama isiksusekeskses 
meditsiinis (Sarsina \& Alivia \& Guadagni 2013). Kesktrendi esindavad üleskutsed võtta vastutus oma tervise kestmise eest, tegeleda elustiiliga seotud haiguste põhjustega ja keskenduda nende ennetamisele. Hea näide on Eesti tervisekursused ja -laagrid, milles osalevad nooremad ja keskealised oma tervisest hoolivad isikud.

Turismi valdkonnas tehtud uurimused juhivad tähelepanu võimalustele ühendada terviseteadlikkuse kasvatamine, pehmed ravivormid ja miljööväärtuslik elamus füüsilise liikumise ja heategevusega. Näiteks on võimalik koguda jalgrattaga sõites raha, et toetada südame tervist, kuid sellel on ka palju laiemad motivaatorid ja tulemused. Heategevus võib sellistel üritustel olla turismist olulisem: me näeme elustiili, mis on seotud ennetava meditsiiniga. Uuringupõhiste alg- ja teiseste andmete kohaselt kattuvad heategevuses osalejad, elustiilihaiguste sotsiaaldemograafilised profiilid ja elustiilihaiguste riskirühmad. Kas jalgrattaga sõitmise lülitamine heategevusürituse programmi annab inimestele reaalse heategevuskogemuse, on omaette küsimus. Tulemused näitavad, et heategevusüritused tutvustavad füüsilise tervise parandamise võimalusi jalgrattaga sõitmise mõjul ja julgustavad looma uusi sotsiaalseid suhteid, samuti edendavad positiivse kogemuse tunnet ja võivad tuua kaasa vaimse tervise ja heaolu paranemise uute sotsiaalsete suhete ja positiivsete emotsioonide tõttu (Ashley \& Boyd \& Goodwin 2000). Ehkki suuna areng on pooleli, on tulemused põhimõtteliselt rakendatavad tervishoiupoliitika hindamisel, samuti on nähtavam sporditurismi roll meditsiinialgatuste toetamisel.

Tänapäeval haarab vabatahtlik tegevus ja filantroopia rikaste inimeste kõrval eri vanuses ja erinevate võimalustega isikuid, millele osutas juba eelnev näide, kus heategevus oli ühitatud turismiga ja millel on laiem tagasimõju ka terviseteraapiana. Heategevus on siiski elustiili muutustest ja isegi olemuslikust pöördest laiem, ehkki just pöörde käigus tähtsustati rohujuure tasandi maailmavaade, kogemused ja elamisviisid. Bénédicte Halba on heategevusest rääkides öelnud, et ühiskonna liikmeks olemine põhineb mitmetel õigustel, kuid toob endaga kaasa ka mitmeid kohustusi teiste liikmete ees (Halba 2014).

Globaalne heategevustrend jääb hetkel mitme (antropoloogilise) uurimisvaldkonna vahealale, kuid avab uusi vaatepiire ka humanitaarseteks uuringuteks ja hõlmab sellisena suhteid alternatiiv-, rahva- ja riikliku meditsiiniteenuse vahel. On tunnuslik, et MTÜdelt ja muudelt kolmanda sektori tegevustelt on solidaarne heategevus laienenud üksikisikutele, mille kohta artikli lõpus esitame mõned näited. Postsotsialistliku meditsiini puutekoht ja erijoon ongi kogukondlik finantseerimine, mida võib nimetada solidaarseks heategevuseks, kuna vabatahtlik tegevus haarab eri vanuses ja erinevate võimalustega inimesi. Robert Putnam, tähtteose "Bowling Alone" autor, on oma uurimustes rõhutanud ühiskonnas eksisteerivate võrgustike, normide ja sotsiaalse usalduse 
tähtsust, mis hõlbustavad tema sõnul koostööd vastastikuse kasu eesmärgil (Putnam 1995: 68). Kui ametlikult on kasvavat huvi vabatahtliku tegevuse ja vabatahtlike organisatsioonide vastu seostatud püüdega ületada lõhe kodanike ja riigi vahel (vt lähemalt Halba 2014: 75 jj), siis üksikisikute motivatsioonid ja eriti nende rühmade abi, kes on ise riskirühma liikmed, vajab alles lähemat vaatlemist, ja seal on usutavasti tihedaid seoseid Robert Putnami viidatud printsiipide ja võib-olla ka Abraham Maslow' osutatud isiksuslike eneseteostuse vajaduste vahel.

\section{Rahastamine väljaspool riiklikku süsteemi, riiklik ja kohaliku valitsuse abi terviseprobleemidega inimestele}

Jätkame moodsa tendentsi vaatlemist, kus tervishoiusüsteemi toetavad edukate inimeste kõrval loomeinimesed, keskklass ning isikud, kes tavaliselt ei kuulu annetajate ja abistajate hulka, vaid on ise abivajajad või selle piiri peal.

Klassikalises stiilis heategevusüritused ehk eeskätt kõrg- ja rikkama keskklassi tuluõhtud - edukate inimeste kallid restorani- või peoõhtud, loosimised, väljamüügid jm üritused on enamasti kas kinnised või vahel ka kaasavad: on silmast silma suhtlemise ja mitmete muude sotsiaalsete tunnustega üritusi, mida kajastatakse seltskonnakroonikas. Tihti on tegemist segarahastusega, sest lisaks meditsiinisüsteemile panustab riik, aga ka kohalik valitsus mitmes valdkonnas, kuid tõstaksin esile vaimupuuetega ja autismispektri häiretega inimeste hoolekandeasutuste (nt Maarja küla, Liikva päikesekodu) ja sama tüüpi ettevõtmiste toetamist. Näiteks Tartu linnal valmis 2019. aastal viis kümnekohalist peremaja intellektipuudega inimestele. Eesmärk on abistada neid iseseisvalt toime tulema ja kogukonnas elama. Kõik peremajad on keskmiselt 300-ruutmeetrise üldpinnaga ja kokku saab sinna uue elukoha 50 inimest. Majad paiknevad linnas lähestikku, asuvad rahulikumas piirkonnas, mis muudab kogu tervise- ja abiteenuse pakkumise kergemaks ja samas hõlbustab ka sootsiumis elamist. ${ }^{3}$

Näiteks Põlvamaa Maarja külas leiame Downi sündroomiga jm diagnoosidega noori, keda õpetatakse elementaarseid töid tegema, iseseisvalt teatud piirides hakkama saama, kunsti- ja käsitööga tegelema. Maarja küla elanike valmistatud käsitööd müüakse kaubanduskeskustes ja mõnedes erapoodides. Selliseid külasid jm toimetulekuga seotud MTÜsid toetab suur hulk kõige populaarsemaid meelelahutus- ja muusikasaateid, mille auhinnad lähevad heategevuseks ja eriti puuetega inimeste peaaegu iseseisva elu korraldamisele. 


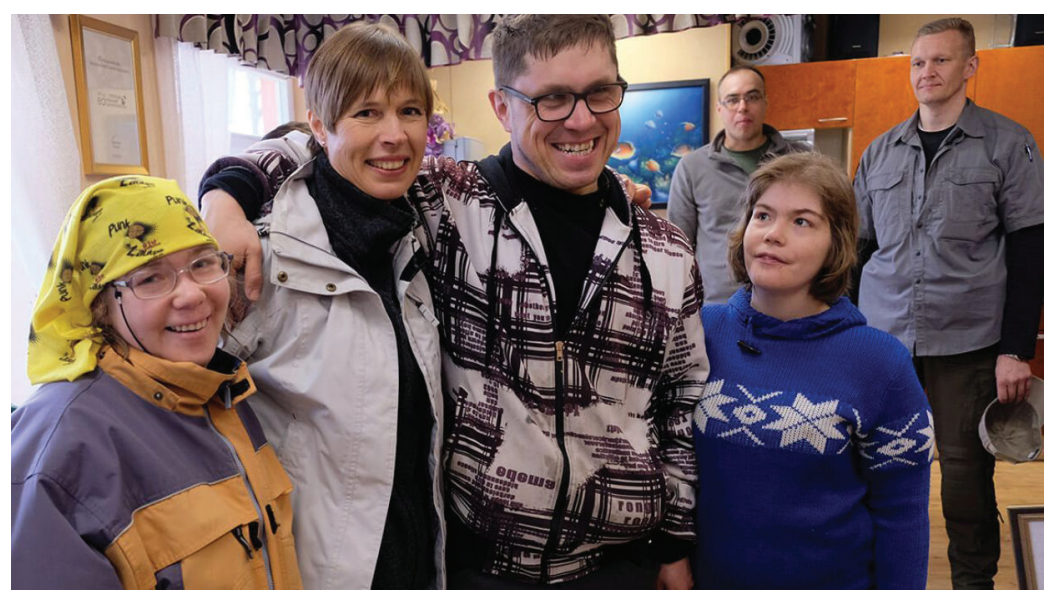

President Kersti Kaljulaid (vasakult teine) on Põlvamaal asuvat Maarja küla väisanud mitu korda. See pilt on tehtud 2018. aasta talgupäeval "Teeme ära”, kui president käis abis just Maarja külas. Foto Maarja küla pildivalikust (https: / / maarjakyla.ee).

\section{Projektid, millega kaasatakse tavalisi inimesi}

Väga selge sõnumi ja tegevusliiniga on spetsiaalsed ühingud, mis on keskendunud ühe haiguse või haiguste rühma patsientide tervisele, nende argielu kergendamisele, informatsiooni jagamisele, patsientide omavahelise suhtlemise korraldamisele, mis on loonud veebifoorumid kogemuste jagamiseks, antakse informatsiooni ravimite jm kohta. Samuti koguvad nad annetusi patsientide heaks (spetsiaalsed ravimid, ravi välismaal). Need organisatsioonid haaravad konkreetse kogukonna osa - patsiendid ja nende lähedased, sõbrad. Organisatsioonidel on ühendus vastavate rahvusvaheliste ühingutega, heategevuskampaaniad toimuvad veebilehtede kaudu.

Meditsiiniantropoloogia seisukohast pakuvad eelmiste kõrval huvi ühiskonna kõiki kihte kaasavad ettevõtmised, millest edukamad on seotud meedia ja perekonna või meediaformaadi ja patsientide koostööga.

Permanentseks ürituseks on kujunenud Eesti Televisiooni heategevussaade "Jõulutunnel", mille algatasid Tiina Kangro ja Grete Lõbu 1999. aastal. Saatel on igal aastal erinev teema, ent teemad on oluliselt seotud haiguste ja tervisega. Selliste formaatide juures kerkib alati küsimus auditooriumi suurusest ja missuguseid vanuserühmasid saade haarab. "Jõulutunnel” on eetris päeva jooksul mitmel korral ning sisaldab teemapõhiseid videolugusid, vestlusi ja muusikute-lauljate etteasteid. Muusika tuleb mõnevõrra vastu publiku maitsele. Intervjuud tutvustavad patsiente, nende haigusi, ravivõimalusi ja 
arutlevad, mida saab sellises olukorras paremaks muuta. Raha kogutakse sissehelistamise abil, annetatavad summad jäävad vahemikku 5, 10, 20 EUR. Aga toetada võib ka saate arvele ükskõik kui sümboolset summat üle kandes. "Jõulutunnelit" iseloomustab vaatajate arvu pidev kasvamine. Saate abil on avatud mitmes linnas liikumispuudega inimeste treeningukeskused, Tartu ja Tallinna lastehaigla vastsündinute ja imikute osakonnas enneaegsete vastsündinute intensiivravi perepalatid. "Jõulutunnel 2017" annetajatelt laekus ligi pool perepalatite kogumaksumusest. Haruldasi haigusi põdevate laste ravi toetuseks koguti 2018. aastal 331622 eurot, mis on saate ajaloo suurim toetussumma.

Viimastel aastatel on saade teinud koostööd näiteks Tartu Ülikooli Kliinikumi Lastefondi esindajatega. See on ka põhjus, miks tehnika ja sisustuse kõrval on tähelepanu all hoopis uus abistamise vorm. Lastefondi esindaja sõnade kohaselt: "Me hakkame kasutama seda raha laste raviks, kes seda vajavad. Ravireisid, millest me rääkisime. Riik tasub operatsiooni välismaal, aga reisikulud peavad maksma pered ise. See on see koht, kus me aidata saame. Meie eelis on see, et oleme kiired. Kui meil on olemas vahendid, siis me saame nendele peredele abi pakkuda!" (EE 2018)

Lastefond toetab üle 400 lapse aastas, mis on suur arv. Olgu võrdlusena öeldud, et USA suurim heategevusfond Transparent Hands Foundation toetab aastas 800 patsienti (Transparent Hands 2017).

On ka heategevussaateid, mis on suunatud üldisemalt laste abistamisele ja kus heategevussõnumid on ümbritsetud teemadega, mis võiksid pakkuda laiemat huvi. Mingis mõttes sarnaneb ettevõtmine jalgrattaturismi ja heategevuse ühitamisega: on mitmeid kõrvalkasusid. Selline oli suurim heategevussaade, mida edastas Kanal 2 - "Kodutunne", mis oli eetris alates 2011. aastast. Saade oli loodud eesmärgiga aidata inimesi, kes mingil põhjusel on hätta sattunud ja ise oma jõududega olukorrale lahendust ei leia. Keskenduti peamiselt lastele, vaatamata sellele, kas nad kuulusid majanduslikesse raskustesse sattunud peredesse, kas nende vanemad olid kaotanud töö, kas oli tegemist vanavanema juures kasvava lapsega, suurperega, raskelt haige(te) lapsevanema(te)ga perega või muu keeruka olukorraga. Saate moto oli: "Igal lapsel on õigus soojale toale, pesemisvõimalusele ning päris oma voodile" (Kodutunne 2018). Saate ehitustegevust rahastasid ettevõtjatest ja eraisikutest annetajad, sageli ka kohalikud inimesed, kes panustasid oma vabatahtliku töö või käsitööga. Eraisikute annetused kogunesid annetustelefonide vahendusel ja olid samuti suuruses 5, 10 või 25 eurot. Saate käigus on ehitatud kortermajadele invalifte, abistatud raskelt haigete vanematega peresid jne. Vaid üks osa saadetest käsitles üksnes meditsiinilisi probleeme.

Näiteks 3. juulil 2019 oli eetris raskekujulist suhkruhaigust põdeva pereema lugu, kelle tütrel oli raskekujuline depressioon. Kehvades oludes perele mindi 
appi seal kasvava väikese tütretütre tõttu. Tihti olidki saate palunud appi lapsed ise, naabrid, valla sotsiaaltöötajad, mõni kaugem sugulane, kes lootis, et saate abi võiks panna õla alla edasisele käekäigu paranemisele.

Saate formaat muutus eetrisoleku jooksul: alustati seebisarjade ülesehitusega, kus kodusest kehvast olukorrast lasti abisaajal korduvalt rääkida, situatsiooni kujunemist ja põhjuseid esitati emotsioone kiskudes, saated olid melodramaatilisuse elementidega ja didaktilise sõnumiga (Wittebols 2004: $38)^{4}$. Tekkiv pinge ja nutvad intervjueeritavad ning kehvade olude detailne visuaalia, lühikesed korratavad episoodid, uue episoodi alustamine eelmise sisu kordamisega tekitas eetilisi küsimusi: kas saadav abi korvab laste eluolu lähivaadete avalikustamise tõttu ohtu sattuva turvalisuse. Hiljem leiti uusi lahendusi ja lähenemisviise - esiplaanile kerkisid hakkamasaamislood saatejuhi poolse sõnumiga - Me ei mõista hukka, vaid aitame. Elus võib kõike juhtuda.

Vaataja jaoks muudeti saade atraktiivseks mitmete lisaefektidega ehk siis saate struktuur ja sisu arenes mitmekihilisemaks: abivajaja ja tema kodu kõrval oli eetris informatsioon vabatahtliku abi ja annetuste kohta: nägime saadetisi saabumas, annetajatele ja ehitajatele jagus pisiintervjuusid, reklaami ja võimalust olla eetris. Mainida tasub teisigi tugevaid kõrvalliine: ehitusnipid, uued remondivõtted, -vahendid ja disain. Arvatavasti oli "Kodutunne" parim ehitussaade, sest ekraanil räägiti lahti, mida ja millest ehitati ning sisuliselt sai huviline saate vältel oskusteavet, kuidas ja milliseid materjale kasutades töid teostada. Huvitav aspekt oli ülimas ruumikitsikuses kaasaegsete hügieeni- ja privaatruumide rajamine. Saatel oli erakordne sisekujundaja Karola Tobro näol, mis tähendab, et pered said endale mõne eliitdisainiga ruumi ja vaatajale räägiti lahti ka kujundusnipid. Soovi korral võis televaataja vaikselt õppida nii disaini kui selle teostamist. Emotsioonid ja ehedad tunded, mida vahendati, tulid selgelt esile. Oskuslik kaameratöö tõi vaataja ette laste ja vanemate rõõmu uutest ruumidest, kingiks saadud mänguasjadest ja mööblist. ${ }^{5}$ Võimalus nautida oma isiklikku voodit ja õpikoha olemasolu oli tajutav ka läbi teleekraani. Ükskõik milline oli vaataja positsioon - heameel abisaanud inimestest või distantseeritum suhtumine - ehedad emotsioonid olid alati tajutavad. Kui lisada juurde spetsiaalsed pagaritooted ja keedised, mida ostes sai samuti kaude toetada kehvas olukorras inimesi, siis osutas kõik heale müügitööle ja täiustuvale süsteemile.

\section{Isiklik abi ja initsiatiiv kolme juhtumi näitel}

Populaarsed on abipalumised konkreetsele isikule, mille seast tõstaksin esile kolm viimasel ajal tähelepanu saanud juhtumit, esitades nende lühikirjelduse. 


\section{Väike Annabel}

Väikesel mõne kuu vanusel Annabelil avastati 2019. aastal üliharuldane geenihaigus - spinaalne lihasatroofia ehk SMA, mida esineb ühel lapsel 10000 imiku kohta. Selle tulemusena ei arenenud edasi Annabeli käte, jalgade ja kaela lihased. Haigusele ravi Eestis puudus, aga Annabeli elu võis päästa üle kahe miljoni euro maksev uudne ravim. 2,2 miljonit eurot koguti Lastefondi ja Annabeli annetuskontodele, millega sellest kujunes Lastefondi ajaloo ja üldse Eesti ajaloos suurima toetussummaga abistamispakett. Annabeli perel tuli tasuda veel Ameerika Ühendriikide meditsiiniteenus ehk ligi 295000 eurot ja kolme kuu elamiskulud USA-s, kuniks meditsiinipersonal jälgib tüdruku tervislikku seisundit ja ravikuuri mõju. Puudu oleva summa kogumise käigus jätkas Tartu Ülikooli Kliinik teadete jagamist perekonna kohta. Just järjepidev teavitamine institutsiooni veebilehel, meedias ja sotsiaalmeedias sidus inimesi teemaga ja andis sobivalt tagasisidet. Rahaliselt aitasid ka ettevõtjad ja Eesti muusikud, kes eraisikute või lauljatena annetasid raha. Muusikute rahakogumisoksjonil kogus nt suurima summa 7000 eurot elektroonilise muusika artist NOËP ehk Andres Kõpper, kes alustas Facebookis oksjonit, mille tulud annetati väikese Annabeli raviks. Suurima pakkumise teinud osaleja võidab NOËPi akustilise lühikontserdi ükskõik millises Eesti paigas - teatas meedia. Teatati näiteks, et paljud muusikud on teinud ka lisapingutuse ja korraldanud rahakogumiseks oksjoneid. Sellega alustas 14. juunil Stig Rästa, kes kahepäevase oksjoniga, kus müüs enda kontserti, teenis 3000 eurot ja sai partnerite toel veel 1600 eurot. Selle juures on ilmselt oluline nimetada, et muusikud on noorema keskea ja noorte lemmikud ehk siis selline valik peaks muutma üldisemalt suhtumist annetusmeditsiini.

"Haruldase geenihaigusega Annabel vajab elu päästmiseks maailma kalleimat ravimit" nii pealkirjastas üleskutse Postimehe terviserubriik, mis selle pildiga kutsus inimesi pisitüdrukut aitama. Foto: HelpAnnabel 2019.

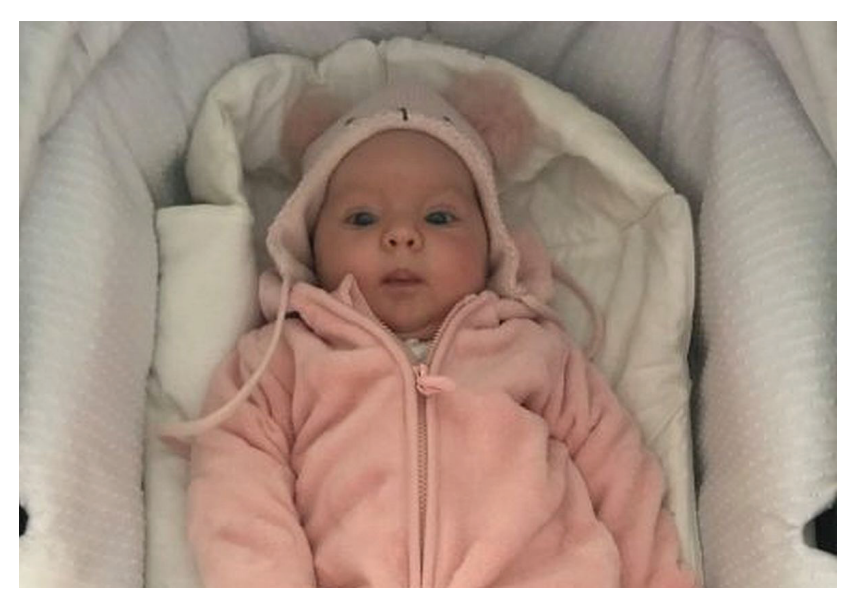




\section{Annabel Lagedilt}

2016. aastal avastati Tallinna lähedases väikses asulas elaval Annabelil pahaloomuline närvisüsteemiga seotud kasvaja neuroblastoom. Avastamise hetkeks oli see endale võtnud poole tüdruku rindkerest, painutanud kõveraks selgroo ning surunud kokku ühe kopsu. Perekond vajas ravimi jaoks 160000 eurot ja neile annetati ühe ööpäeva jooksul 350000 eurot. Raha kandsid üle näiteks ka Annabeli koolikaaslased, sh algklasside lapsed, kes annetasid oma taskuraha. Suurema osa annetajatest moodustasid erinevates paikades elavad inimesed, kellele meeldis perekond ja Annabel ja kes tegutsesid silmapilkselt. Ülejäänud raha andis perekond edasi vähiravifondile ja sellega sai abistada veel mitut vähihaiget (Elu24 2017; Kingitud Elu 2017).

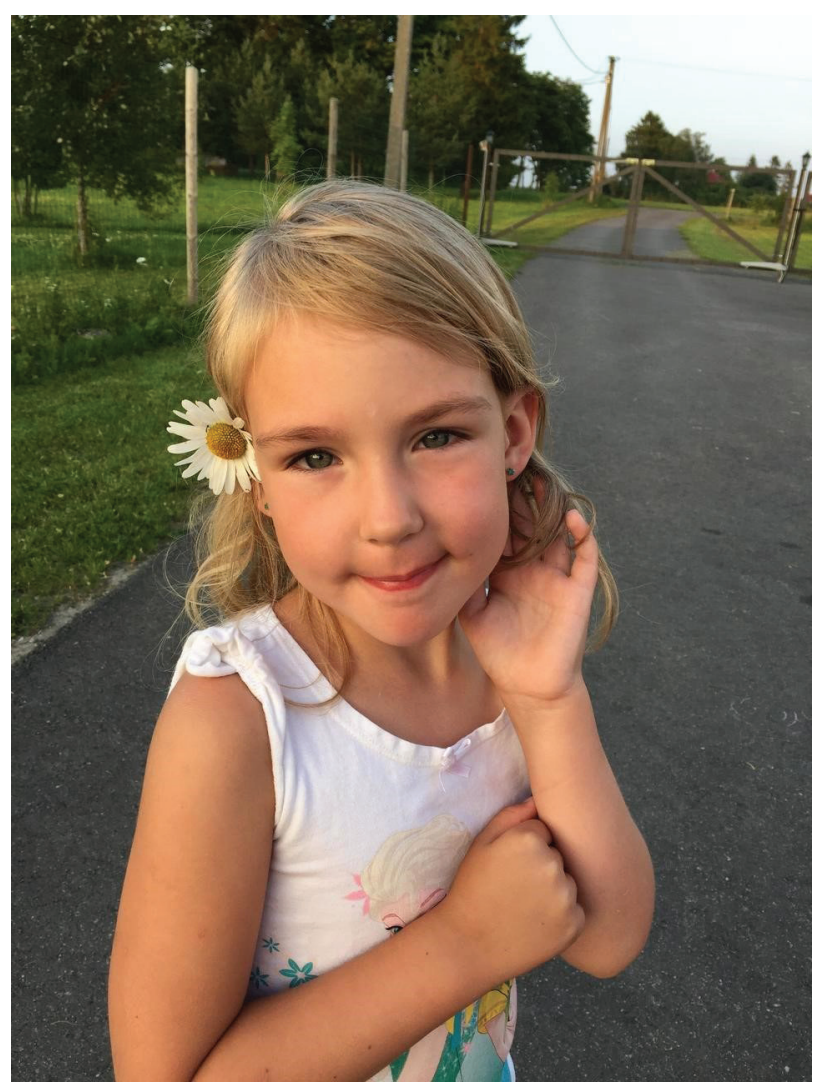

See pilt ilmus 2017. aastal nii vähiravifondi Kingitud Elu Facebooki lehel kui ka Postimehes Annabelist, tema haigusest ja ravimitoetuseks annetatavast summast rääkivate uudiste juures. Foto: vähiravifond Kingitud Elu 2017. 


\section{Suitsiidiproblemaatika}

Mõned teemad avavad ühiskonnas teatava paise ja üheks selliseks oli kahtlemata suitsiidi temaatika. Kuigi enamik eestlastest näib tunnustavat inimese õigust valida oma elu pikkust ja kvaliteeti ja justkui pooldab teatud haiguste, vanaduse jm juhtumitel suitsiidi, jagunesid ühe juhtumi alusel siiski inimesed mitmesse leeri.

Kuigi Eesti ei ole Euroopas suitsiidide arvult esireas, võtsid meedikud mitmete lootusetus seisus haigete enesetappude järel traagilise tooni ja kogu sündmustik päädis Eesti Sotsiaalministeeriumi tellitud uuringuga. Tulemustes rõhutati, et aastatel 2006-2016 hukkus Eestis enesetapu tõttu 2543 inimest ehk 231 inimest aastas.

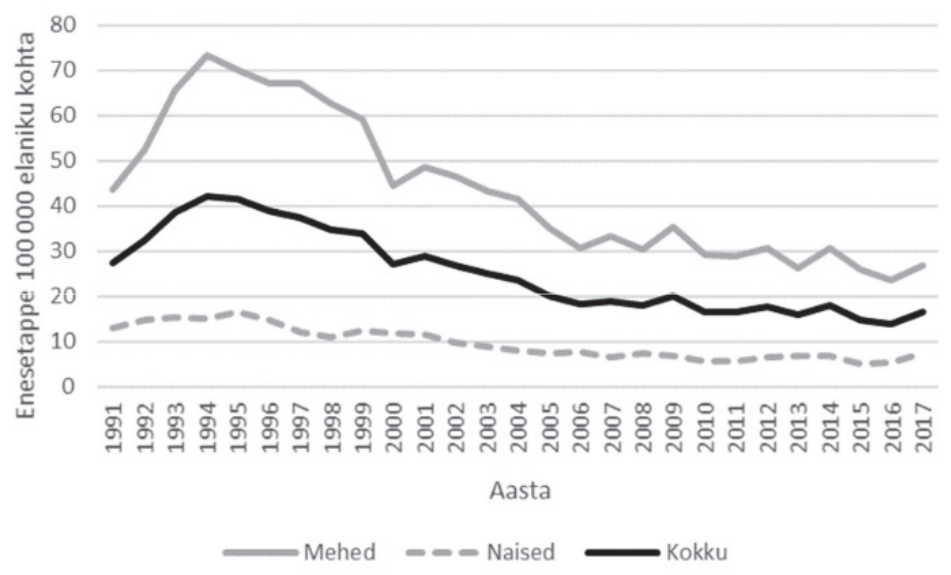

Joonis 1. Suitsiidide üldsuremuskordajad Eestis 1991-2017, allikas Statistikaamet. Rooväli, Pisarev, Suija, Aksen ja Uusküla 2018.

Meedias jäi vaatluse alt välja selline oluline tegur nagu lõppstaadiumis fataalsed haigused, tähelepanu all olid tegurid, millest üldistati kaaskondsete toimetulekumudeleid ja abivajadust, otseselt vajadust põhjuseks olevate keerukate küsimustega esile ei toodud (Rooväli et al. 2018). Uurimus toob esile ka, et suurimad (eriti venekeelse elanikkonna hulgas) suitsiidinäitajad olid 1980. ja eriti 1990. aastate alguses, ebaselgetes oludes. Sealt alates on suitsidaalsus Eestis langenud. Statistiline analüüs sattus meedia poolt teravdatud hetkele (teismelise enesetapp), kuid ei pakkunud lahendusi reaalsetele probleemidele. 
Sotsiaalmeedia reaktsioonide tulisus viitas aga vajadusele problemaatikaga sisuliselt tegeleda.

Inimeste rahalise toetuse pälvis 47aastane endine tantsuõpetaja, kes sooritas 2019. aasta märtsikuus Šveitsis abistatud suitsiidi. Nelja lapse ema Jane Paberit põdes amüotroofilist lateraalskleroosi ehk ALSi, mis lülitas tema keha järk-järgult välja. Saate meeskond jälgis haiguse kulgemist aasta vältel, tehes temaga intervjuusid, mistõttu ka televaatajal oli võimalik näha haiguse progresseerumist ääretult intelligentsel ja säraval naisel. Viimaste intervjuude ajal olid tal rääkimisraskused ja käed olid välja lülitumas, mida ta ka demonstreeris kaamerate ees. Kohaliku asula rahvas korraldas vaprale naisele suure hüvastijätupeo. Naise üks põhjendusi oli ka, et ta lastel pole võimalik pakkuda talle erihooldust, ning teades täpselt haiguskirjeldust ei tahtnud ta olla oma kehas vangis. Viimased kaadrid näitasid teda ratastoolis sõitmas ja tundmas rõõmu lapselastest.

Jane Paberit sai inimestelt nii palju annetusi, et sai omakorda kanda ALSi Seltsile üle 22000 eurot (Ubaleht 2019), et fond saaks toetada ka teisi abivajajaid.

Oma postuumses raamatus, mille tulud olid määratud abistama abivajajat, kirjutab ta:

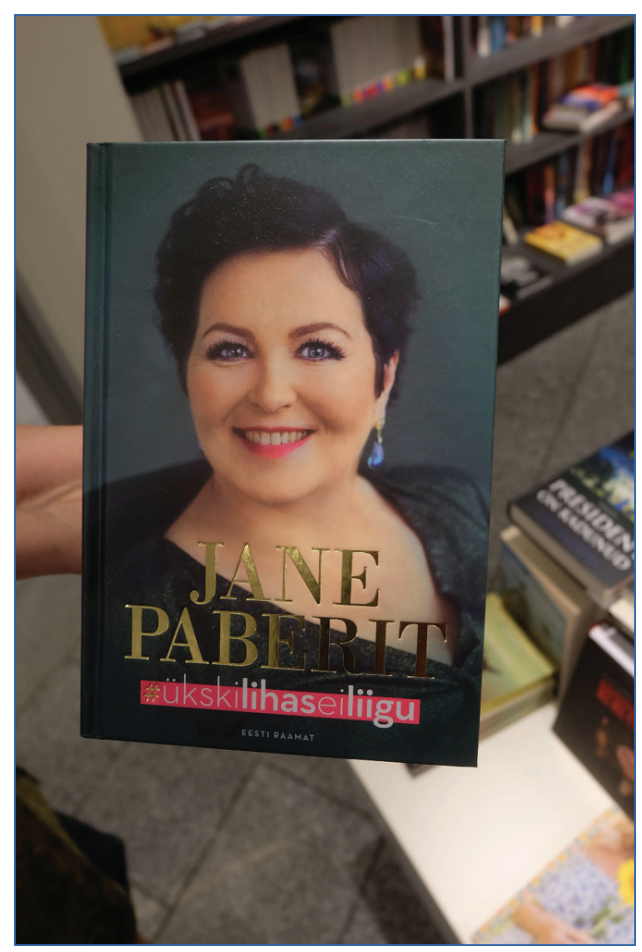

Olen alati mõelnud, et kunagi kirjutan raamatu. Oma elust. Nii palju on saanud nalja, nii palju on olnud uskumatuid seiklusi, kokkusattumusi, kurbust ja õnne.

Kirjutada mulle meeldib. Ja pensionäripõlveks on mälestused settinud kullaks ja mullaks. Liigne emotsioon ja ebaolulised seigad on minema hõljunud, jäänud on vaid ehtne ja hea. Nii ma arvasin. Mida ma arvata ei osanud, on see, et kirjutan raamatu juba nü̈̈d, neljakümne seitsmesena, kiiruga, telefonis ühe sõrmega tippides. Ja mõeldes mitte oma elust, vaid suremisest. (Paberit 2019) 
Abistatud suitsiid on hetkel legaalne ainult viies riigis ja Eesti nende hulka ei kuulu. Eesti lugejaskond jagunes Paberiti juhtumi valguses kommentaaride ja ajaleheartiklite alusel pigem ametiisikute vastuseisuks ning ülejäänud rahvastik vastavalt tõekspidamistele ja isiklikele kogemustele vastu-, poolpooltja poolthäälteks. Mõistmist suurendas kogemus kümneid aastaid voodihaige põetamisega või mõne raske vähivormiga kokkupuutumine.

\section{Missugused on kaasava meditsiini ja kaasava rahastamise (crowdfunding) kaasnähtused?}

Heategevusorganisatsioonidel on umbkaudu 125 aasta pikkune ajalugu ja nende puhul on rõhutatud, et probleemid on maailmas sarnased ning neile tuleb leida ühine lahendus. Et leida nn üks globaalne lahendus, tuleb ühendada kõik võimalused ja selles osas seisab palju alles ees.

Üritasin vaadelda vabatahtliku tegevuse kahte suunda. Ühelt poolt riiklikku toetust näiteks peresüsteemis elamise võimalusele ja kodanike õhutamist iseseisvale elule, mis on toonud kaasa ka vastavad ehitised. Teisalt on vabatahtlik tegevus laiemalt kodanikke kaasav liikumine, millel on mitmeid uusi vorme ja sellel on üsna oluline roll mitmes valdkonnas, kindlasti ka meditsiinis. Vabatahtlikkus võib põhineda soovil oma oskusi jagada, kuid võib tähistada ka igivana solidaarsust kogukonna liikme suhtes.

Meediavahendus on toonud esile kannatuste reaalse külje ilma metafoorideta, ilma pettekujutusteta. See tõi omakorda kaasa tulised arvamustevahetused. Arstide vahelised ja kodanike arutelud abistatud suitsiidi osas tõid esile suured lahknevused. Näiteks meie osakonna küsitlused osutavad, et inimesed on valdavalt selle teenuse poolt, arstid aga kõhklevad, osutades muu hulgas küsimuste ringi keerukusele ja juriidilise külje puudumisele. Samas näitab päevalehtede kommentaariumite analüüs, et protsessi alguses suhtuti otsusesse positiivselt, lõpus tekkisid aga pooldajate kõrvale äärmustrollide, konservatiivide (kristlaste?) ja altruismi sooneta kommenteerijate rühmad, kes sajatasid südametunnistusepiina haige lähedastele ja ületasid eetilisi piire.

On ka ilmne, et paljud annetajad ootavad imet, milleks haruldane ravim, kauge mütiseeritud meditsiinikeskus vms justkui pakuks lahenduse, millele omakorda püüdsid vastu astuda realistid (EFITA). Usuti tüvirakkude siirdamise ja eksperimentaalse ravi võimekusse. Väiksemate meditsiiniliste teadmiste ja ilmselt väheste võimaluste arvelt solidaarsustoetuse teinud annetajad olid sageli rohkem pettunud vähestes ja aeglastes edusammudes. Nende meelest oli imelik, et raske haiguse käes vaevelnud Annabel võluväel ja täielikult ei paranenud. See on annetusmeditsiini ja eriti kogukonna laiapõhjalise solidaarsusmeditsiini kaasnähtus. 
Kuna kaasav rahastamine on alles arenemas, siis on nii haiguste ravimise toetamine kui ka annetamise ja altruismi mõisted ja mõistmine alles kujunemas. Seda poolt kajastavad pettumus, et teha ei saa ühe-kahe euro suurust annetust, et telefoniliinide vahendajad võtavad selle pealt tasu, et saate produtsent teenib heategevussaadetega elatist, ja need ei ole tagasihoidlikud summad. Kõige selgemalt väljendus see "Kodutunde" saate produtsenti tabanud kohtusüüdistusega seoses, kui paljusid annetajaid rabas reaalsuse karm sõnum.

On ilmne, et heategevusmeditsiini ja heategevussaadete produtsentidel ja saatejuhtidel on olnud lähem kokkupuude raske haiguse, kroonilisele või fataalsele haigusele kaotatud lähedastega, keerulised isiklikud kokkupuuted kaasasündinud kahjustusega laste või dementsusele kaotatud sugulase või kaaslasega (seda osutab ka nt Väli 2016 kokkuvõte). On juhitud tähelepanu, et intervjuud perekonnaliikmetega ja isiklik sümpaatia noorte ja atraktiivsete perede suhtes tähendab ka selles valdkonnas, et võrdsust on raske saavutada ja sarnased tõmbavad sarnaseid. Ent siiski on see tänases ühiskonnas - ja mitte ainult Eestis - asendamatu lisa ametlikult pakutavatele lahendustele.

Annetuste ja kodanike osalusega seotud teemade positiivsele poolele jääb siiski palju jooni:

1. Rahaline abi seal, kus muid finantsvõimalusi ei ole.

2. Üldine meditsiiniteadlikkuse kasvamine. Intervjuud ja arstide selgitused aitavad paremini kui kunagi varem mõista mitte ainult kroonilisi ja ravimatuid haigusi nagu vähk, diabeet, astma, südamepuudulikkus, autismi rasked vormid, aga ka haruldasi geneetilisi haigusi ja hädaolukordasid, milles viibivad haiged ja nende lähedased.

Näiteks jättis vaatajatele sügava mulje intervjuu viieaastase rõõmsa Mihhaili ja tema emaga nende kodus Narvas. Mihhail sündis ilma sisekõrvata, st tal puudusid sisekõrva struktuurid, mis on harva esinev haigus, Micheli aplaasia. Võib arvata, et niisugusest sünnipärasest rikkest polnud vaatajad varem kunagi kuuldud. Sünnitusmajas avastatud haigusele on otsitud abi sünnist alates: Mihhail on käinud kolm korda Saksamaal operatsioonil ja kahjustuse kõrvaldamiseks on tehtud parim, mida saab pere ette võtta, ent ees seisab pikk teekond. See on vaid üks näide paljudest intervjuudest, haigustest, millest tavaline vaataja pole kuulnudki.

3. Mitmed kõrvalteadmised, mida saadakse saadete ja veebikogukondade vahendusel: põetamine, informatsioon elementaarsete abivahendite osas, aga ka nt teadmised hoopis muudes valdkondades ehitusest kujundamiseni, erinevatest praktilistest majapidamisnippidest. 
4. Selle temaatika kaudu tuleb nähtavale tänase solidaarsusliikumise erijoon: noorte ja meeste vabatahtliku abiga liitumine, nende annetuste sagenemine. See osutab laiematele muutustele ühiskonnas, nagu ka 1990. aastatel alanud uus filantroopiasuund - panustada enda teenitud tulu olulisel määral ühiskonda.

5. Uudne on võimalus ja tahe väljendada solidaarsust ning humaansust isegi sel juhul, kui su võimalused on väikesed. See aitab põimida ühiskonna liikmeid ning neid lähendada, mõista toimuvat - tegemist on ilmselt inimomase käitumise fraktalitega.

6. Keeruliste küsimuste tõstatamine ühiskonnas, mille seas on nii haruldased haigused, invaliidsus, geneetilised haigused kui ka abistatud suitsiid ja elu lõpuga seotud probleemid.

\section{Tänusõnad}

Uurimistöö toimus IUT 22-5 ja sellele järgnenud projekti EKM 8-2/20/3 "Narrative and belief aspects of folklore studies" plaaniliste uuringute raames ja on seotud Eesti-uuringute Tippkeskuse (TK 145) mütoloogia ja usundirühma tegevusega.

\section{Kommentaarid}

1 Heategevust laiemas kontekstis on analüüsinud Kaarna 2011; Kaarna \& Noor 2011; Mänd et al. 2011; EMOR 2009, 2013; firmade annetusi fondile Kingitud Elu (asutatud 2014) on vaadelnud bakalaureusetöös Marlen Väli (2016). Risto Kaarna (2011) andmetest selgub, et tasustamata regulaarset (rohkem kui kord aastas) vabatahtlikku tööd tegi aastatel 2009-2010 4,5 protsenti Eesti elanikest, kes on vanemad kui kümme aastat ja neist 92,6 protsenti on eestlased. Organiseeritud vabatahtlike osakaal kõigist vabatahtlikest oli 35,8 protsenti. Ka EMOR 2013 toob esile, et soositum on isiklik annetus abi vajavale isikule ( $41 \%$ annetajate valik). Urmo Kübar ja Andrei Liimets (2020) toovad esile annetajate arvu kasvu viiendiku võrra pandeemia aastal.

2 Filantroopia andekate, kuid majanduslike võimalusteta noorte suhtes on eksisteerinud ajast aega ja põhimõtteliselt selles osas olulisi katkestusi kindlasti polnudki. Omaette teema on, et seda ei saanud avalikult meedias jm demonstreerida. Vaadates koolipärimuse internaadi temaatikaga laekunud vastuseid on tegemist tähtsa väärtuste ja hariduspüüdluse alateemaga.

3 Põhimõtteliselt on tegemist riskiprojektiga nagu tavaklassidesse puudega või häiritud tähelepanuga laste kaasamine, mis on lõppemas. Toimetus juhtis autori tähelepanu, et 7. juuli 2020 edastati info, et peremajad on alatäidetud, sest inimesed ei saa seal hakkama. Küsimus ei ole mitte tervises, vaid toimetulekus. 
${ }^{4}$ Autor eristab USA jõukama keskklassi vaateid ja mudeleid edastavaid USA seebisarju inglise tööliste elule keskenduvatest sarjadest, mille sõnumid erinevad üksteisest.

5 Pikaaegne saade lahkus teleekraanilt keset koroonakriisi suure skandaaliga ja asendati samalaadse formaadiga "Hingesoojus" oktoobris 2020. Esialgsed kommentaarid olid seinast seina, esitati küsimusi ehituskvaliteedi, saatejuhi tausta, sotsiaalsete olude, abistatavate eluolu mõjutanud isiklike valikute jpm probleemide kohta. 17. novembril 2020 andis Kanal 2 omanik ja programmijuht Jüri Pihel intervjuus teada, et saate tegemine peatatakse õigusliku selguse saamise huvides (Paju \& Toomemets \& Närep 2020).

\section{Allikad}

EFITA - Eesti Kirjandusmuuseumi folkloristika osakonna teadusarhiiv

\section{Kirjandus}

Ashley, Caroline \& Boyd, Charlotte \& Goodwin, Harold 2000. Pro-Poor Tourism: Putting Poverty at the Heart of the Tourism Agenda. Working paper. Natural Resources Perspectives 51. London: Overseas Development Institute.

Barry, Jonathan \& Jones, Colin (toim) 1991. Medicine and Charity Before the Welfare State. New York \& London: Routledge.

Bialecki, Jon \& Girish Daswani 2015. What is an Individual? The View from Christianity. HAU Journal of Ethnography Theory 5 (1), lk 271-94 (doi: 10.14318/hau5.1.013).

Borsay, Anne 1999. Medicine and Charity in Georgian Bath: A Social History of the General Infirmary, c. 1739-1830. History of Medicine in Context. London: Routledge.

Borsay, Anne \& Shapely, Peter 2016 [2007]. Medicine, Charity and Mutual Aid: The Consumption of Health and Welfare in Britain, c. 1550-1950. New York \& London: Routledge.

CMAC 2020 = Charity Medicines Access Coalition. Alzheimers Research UK (https:// www.alzheimersresearchuk.org/about-us/our-influence/policy-work/charity-medicinesaccess-coalition/ - 30. november 2020).

Coleman, Simon 2006. Materializing the Self: Words and Gifts in the Construction of Charismatic Protestant Identity. Cannell, Fenella (toim). The Anthropology of Christianity. Durham \& London: Duke University Press, lk 163-184 (doi: 10.1215/9780822388159006).

EE 2018 = FOTOD | Eestlased on helde rahvas! Haruldaste haiguste käes kannatavate pisikeste heaks on kogutud 280000 eurot. Eesti Ekspress, 25. detsember (https://lood. delfi.ee/kino/fotod-eestlased-on-helde-rahvas-haruldaste-haiguste-kaes-kannatavatepisikeste-heaks-on-kogutud-280-000-eurot?id=84851879 - 2. detsember 2020). 
Elu24 2017 = Üleskutse toetada 7-aastase Annabeli ravi tõi vähiravifondi ühe päevaga 200000 eurot! Postimees, Elu24 26. oktoober (https://www.elu24.ee/4289585/uleskutsetoetada-7-aastase-annabeli-ravi-toi-vahiravifondi-uhe-paevaga-200-000-eurot 2. detsember 2020).

EMOR 2009 = Vabatahtlikus tegevuses osalemine Eestis. II osa. Uuringu aruanne. Tallinn: Praxis, TNS Emor (http://praxis.ee/fileadmin/tarmo/Projektid/Valitsemine_ja_ kodanike\%C3\%BChiskond/Vabatahtlikus_tegevuses_osalemise_uuring/Vabatahtlike_ uuring_II_osa_Loplik.pdf - 2. detsember 2020).

Emor 2013 = Heategevusalaste hoiakute uuring 2013. Uuringu aruanne. September 2013. TNS EMOR (https://www.kysk.ee/failid/File/Uuringud/Aruanne_heategevus_2013. pdf - 2. detsember 2020).

Engel, Jonathan 2006. Poor People's Medicine: Medicaid and American Charity Care since 1965. Durham \& London: Duke University Press.

Firth, Raymond 1996. Religion: a Humanist Interpretation. London and New York: Routledge.

Gorelova, L. E. \& Surovtseva, T. I. \& Sechenov, I. M. 2014. Zemstvo district medicine and charity in Russia. Istoria mediciny 4 (4), lk 29-34.

Halba, Bénédicte 2014. Volunteering from altruism to otherness. Traditiones 43 (3), lk 67-87 (doi: 10.3986/Traditio2014430304).

Hiiemäe, Reet \& Kalda, Mare \& Kõiva, Mare \& Voolaid, Piret 2020. Koroonakriisi rahvapärased väljendused Eestis. Folkloori taaskasutus kui toimetulekuviis. Keel ja Kirjandus 12, lk 1011-1032.

Hiiemäe, Reet \& Utriainen, Terhi 2021. From "unbelievable stupidity" to "secret clues for staying healthy": CAM landscape and boundary-work in Estonian and Finnish mainstream media in April 2020. Folklore: Electronic Journal of Folklore 81 [ilmumas].

Kaarna, Risto 2011. Heategevuse majanduslik väärtus, mõju ja väärtustamine. RiTo 24 (https://rito.riigikogu.ee/wordpress/wp-content/uploads/2016/02/Heategevusemajanduslik-v\%C3\%A4\%C3\%A4rtus.pdf - 2. detsember 2020).

Kaarna, Risto \& Noor, Külvi 2011. Ülevaade vabatahtliku töö majandusliku ja sotsiaalse väärtuse hindamise võimalustest. Tallinn: Praxis (http://www.praxis.ee/fileadmin/ tarmo/Projektid/Valitsemine_ja_kodanike\%C3\%BChiskond/VKP_VABAmet_16ppraport. pdf - 30. november 2020).

Kidd, Alan J. 1996. Philanthropy and the 'Social History Paradigm'. Social History 21 (2), lk 180-192 (doi: 10.1080/03071029608567968).

Kingitud Elu 2017 = Vähiravifond ulatab abikäe 7-aastasele Annabelile. Raviks vajalik hiigelsumma kogunes fondi ühe päevaga! Vähiravifond Kingitud Elu, 24. oktoober (https://kingitudelu.ee/uudised/vahiravifond-toetab-7-aastase-annabeli-voitlust-elu-eestning-kutsub-koiki-vaikese-vapra-printsessi - 2. detsember 2020).

Kodutunne 2018. Vikipeedia (https://et.wikipedia.org/wiki/Kodutunne - 30. november 2020). 
Kõiva, Mare 2020. Pandemic Driven, Citicen Philantropy. COVID-19 - I. Management Strategies and Communication Models, On-line Seminar, 18. august (http://www.folklore. ee/rl/fo/konve/2020/covid_I/ - 30. november 2020).

Kõiva, Mare 2021. Ia smotrela na mir, i eto bylo strashno. Strakh v etnopsikhiatrii. Meditsinskaia antropologiia i bioetika [ilmumas].

Kübar, Urmo \& Liimets, Andrei 2020. Eesti heategevuse ellujäämisaasta 2020. Hea kodanik. Uudised (https:/heakodanik.ee/uudised/eesti-heategevuse-ellujaamisaasta2020-osa-iii/ - 2. detsember 2020).

Mägi, Maiken 2018. Rekordilised jõuluannetused: koolinoorte heldus lõi vähiravifondi pahviks. Postimees. Elu24 (https://tervis.elu24.ee/4371805/rekordilised-jouluannetusedkoolinoorte-heldus-loi-vahiravifondi-pahviks - 2. detsember 2020).

Mänd, Kristina \& Noor, Külvi \& Uus, Maiu \& Uudelepp, Annika 2011. Väärikaks ja õnnelikuks: annetamise analü̈̈s ja soovitused. Lõppraport. Tallinn: Praxis (http:// www.praxis.ee/fileadmin/tarmo/Projektid/Valitsemine_ja_kodanike\%C3\%BChiskond/ Annetamise_analyys_Praxis_2011_fin.pdf - 2. detsember 2020).

Paberit, Jane 2019. \#̈̈kskilihaseiliigu. Tallinn: Eesti Raamat.

Paju, Keit \& Toomemets, Katharina \& Närep, Merilyn 2020. LÕPP SEL LOOL! Jüri Pihel: pole teada, kas, millal ja kuidas me "Hingesoojusega" jätkame. Katrin Lust: olen täitsa jahmunud! Õhtuleht, 17. november (https://elu.ohtuleht.ee/1017942/lopp-sel-looljuri-pihel-pole-teada-kas-millal-ja-kuidas-me-hingesoojusega-jatkame-katrin-lust-olentaitsa-jahmunud - 2. detsember 2020).

Putnam, Robert D. 1995. Bowling Alone: America's Declining Social Capital. Journal of Democracy 6 (1), lk 65-78 (https://www.journalofdemocracy.org/articles/bowling-aloneamericas-declining-social-capital/ - 30. november 2020).

RaKS 2002 = Ravikindlustuse seadus. Vastu võetud 19.06.2002. Riigi Teataja (https:// www.riigiteataja.ee/akt/113032019136 - 2. detsember 2020).

Research on Ageing and Care 2018-2025. Centre of Excellence in Research on Ageing and Care (CoE AgeCare) Universities of Jyväskylä, Tampere and Helsinki (https://www.jyu. fi/hytk/fi/laitokset/yfi/en/research/projects/research-groups/carpo/centre-of-excellence-inresearch-on-ageing-and-care-coe-agecare - 2. detsember 2020).

Rooväli, Liis \& Pisarev, Heti \& Suija, Kadri \& Aksen, Merli \& Uusküla, Anneli \& Kiivet. Raul-Allan 2018. Aastatel 2006-2016 enesetapu sooritanute epidemioloogiline ülevaade. Tartu: Tartu Ülikooli peremeditsiini ja rahvatervishoiu instituut (https://www.sm.ee/ sites/default/files/content-editors/Tervishoid/rahvatervis/suitsiid_lopparuanne_pikk. pdf - 30. november 2020).

Sarsina, Roberti P. \& Alivia, Mauro \& Guadagni, P. 2013. The contribution of traditional, complementary and alternative medical systems to the development of person-centred medicine - the example of the charity association for person-centred medicine. $O A$ Alternative Medicine 1 (2) (doi: 10.13172/2052-7845-1-2-655).

Sterling, Peter 2018. Point of View Predictive regulation and human design. eLife 2018;7:e36133 (doi: 10.7554/eLife.36133 - 30. november 2020). 
Sterling, Peter 2020. COVID-19 and the Harsh Reality of Empathy Distribution. Scientific America (https://blogs.scientificamerican.com/observations/covid-19-and-theharsh-reality-of-empathy-distribution/ - 30. november 2020).

Tartu Linnavalitsus 2018 = Ühed Maarja peremajad saavad nurgakivi, teistes peetakse sarikapidu. Tartu Linnavalitsuse pressiteade, 12. detsember (https://www.tartu.ee/en/ node/9014 - 30. november 2020).

Transparent Hands 2017 = List Of Top 15 Charity Organizations in USA. Transparent Hands. Reaching Down and lifting people up (https://www.transparenthands.org/listof-top-15-charity-organizations-in-usa/ - 30. november 2020).

Ubaleht, Marianne 2019. Eesti esimene eutanaasiaturist Jane Paberit annetas ALS-i fondile hiigelsumma raha: arvan, et see ei ole veel kõik, sest ikka veel tuleb ülekandeid. Delfi, 27. jaanuar (https://www.delfi.ee/news/paevauudised/eesti/eesti-esimeneeutanaasiaturist-jane-paberit-annetas-als-i-fondile-hiigelsumma-raha-arvan-et-seeei-ole-veel-koik-sest-ikka-veel-tuleb-ulekandeid?id=85140819 - 30. november 2020).

Valge, Pirkko \& Kübar, Urmo \& Sarapik, Rivo 2020. Heategevus kui investeering. Podtail, 5. august. Investeerimisklubi (https://podtail.com/en/podcast/investeerimisklubi/ heategevus-kui-investeering-pirkko-valge-urmo-kuba - 3. detsember 2020).

Vasold, Manfred 1999. Pest, Not und schwere Plagen: Seuchen und Epidemien vom Mittelalter bis heute. Augsburg: Bechtermunz.

Väli, Marlen 2016. Heategevuse toetamine ettevõtete poolt vähiravifondi "Kingitud Elu” näitel. Bakalaureusetöö. Tallinn Tallinna Tehnikaülikooli Majandusteaduskonna Ärikorralduse instituut, turunduse õppetool (https://mi.ee/sites/default/files/ bakalaureusetoo_marlen_vali.pdf - 3. detsember 2020).

Wittebols, James H. 2004. The Soap Opera Paradigm: Television Programming and Corporate Priorities. Oxford: Rowan ja Littlefield, inc.

\title{
Summary
}

\section{Charity and solidarity medicine problems: The Estonian case}

\author{
Mare Kõiva \\ Leading Research Fellow \\ Department of Folkloristics, Estonian Literary Museum \\ mare@folklore.ee
}

Keywords: altruism, assisted suicide, donation medicine, solidarity

Alternative, folk, and state medicine services intersect in the spheres of voluntary assistance and joint financing, donation medicine, charity movement, and solidary charity. Voluntary activity involves many people in different age groups and with different opportunities, and is wider than changes in lifestyle and an inherent turn to local activities 
and stances. The global trend remains in the transitional area of different domains, yet its deeply humane message, joint assistance to people in an emergency situation, constitutes the continuation of traditional means of assistance in today's society. Charity medicine has opened up new topics for humanitarian studies. The article discusses the state and local institutions' supportive activities for health care and, for example, for the coping strategies of people with severe health damage, as well as the support provided by different media channels for people with health issues, and voluntary help based on personal free will. The article focuses on the following questions: What is the status of solidarity in today's medicine and welfare services? What are the characteristics, approaches, and results of charity medicine in Estonia? What questions are raised by charity? Do we deal with only medical and health issues or with human fractals?

Mare Kõiva on Eesti Kirjandusmuuseumi juhtivteadur ja folkloristika osakonna juhataja ning Eesti-uuringute Tippkeskuse juht. Tema teadustöö keskendub loitsudele ja rahvaravitsejatele, rahvausundile, Eesti diasporaale, mütoloogiale ja kaasaegsele folkloorile. Ta on "Folk Belief Today" (1995), "Media, Folklore, Mythology" (2000), "Eesti loitsud" (2011), "Eesti loitsud I. Arstimissõnad I" (2019) nja teiste monograafiate autor, kogumike koostaja ja artiklite autor. Tema peamine välitööde ala on Eesti, Bulgaaria ja Valgevene.

Mare Kõiva, is a Leading Researcher and the Head of the Department of Folkloristics at the Estonian Literary Museum, Tartu, Estonia. She is the Head of the Center of Excellence in Estonian Studies. Her research focus is on incantations and folk healers, folk religion, Estonian diaspora, mythology and contemporary folklore. She is the author of 'Folk Belief Today' (1995), 'Media, Folklore, Mythology' (2000, in Estonian) 'Estonian incantations' (2011, in Estonian), 'Estonian Incantation I. Healing words I' (2019, in Estonian) and lots of other monographs, compilations and articles. Her main area of the field reasearch is Estonia, Bulgaria, Byelorusia.

mare@folkore.ee 